\title{
SPONGE SPICULES IN PEATY SEDIMENTS AS PALEOENVIRONMENTAL INDICATORS OF THE HOLOCENE IN THE UPPER PARANÁ RIVER, BRAZIL
}

\author{
MAURO PAROLIN \\ Programa de Pós-Graduação em Ecologia de Ambientes Aquáticos Continentais, UEM, Rua Chafic Bader Maluf, 21, \\ 87300-170, Campo Mourão, PR, Brazil.mauroparolin@gmail.com \\ CECÍLIA VOLKMER-RIBEIRO \\ Museu de Ciências Naturais, Fundação Zoobotânica do Rio Grande do Sul, Cx.P. 1188, 90001-970, Porto Alegre, \\ RS, Brazil.cvolkmer@fzb.rs.gov.br \\ JOSÉ CÂNDIDO STEVAUX \\ Universidade Guarulhos, Programa de Pós-Graduação em Análise Geoambiental, Pr. Teresa Cristina, 1, 07023-070, \\ Guarulhos, SP, Brazil. jstevaux@prof.ung.br
}

\begin{abstract}
The presence of freshwater sponge spicules was analyzed in samples of peaty sediments obtained in two vibro-cores from the Taquarussu region ( $22^{\circ} 30^{\prime} \mathrm{S}, 52^{\circ} 20^{\prime} \mathrm{W}$, Mato Grosso do Sul State, Brazil). Four samples were dated by $14 \mathrm{C}$ method as $11,570 \pm 80$ years BP (depth $240 \mathrm{~cm}), 9,710 \pm 80$ years BP (depth $220 \mathrm{~cm}), 4,610 \pm 70$ years BP (depth $130 \mathrm{~cm}$ ) and 4,010 \pm 80 years BP (depth 29-35 cm). The freshwater sponges detected were Heterorotula fistula Volkmer-Ribeiro \& Motta, 1995, Radiospongilla amazonensis Volkmer-Ribeiro \& Maciel, 1983, Corvospongilla seckti Bonetto \& Ezcurra de Drago, 1966 and Trochospongilla repens Hinde, 1888. The first two species are typical of lentic environments and the other two of lotic habitats. These two pairs of species are found in alternating throughout the length of core 2, indicating flooding pulses, which may be responsible for the peat formation and accumulation along the river Esperança marginal embayments during the Holocene. There is also evidence of a wetter period between 4,610 and 4,010 years BP. The results corroborate the palynological studies previously produced for the region. This is the first dated fossil record of Heterorotula fistula and Trochospongilla repens.
\end{abstract}

Key words: freshwater sponges, siliceous spicules, flood pulse, Holocene, peaty deposits.

RESUMO - Foi analisada a presença de espículas de esponjas de água doce em amostras de sedimentos turfosos obtidas em duas perfurações com “vibro-core” na região de Taquarussu (Mato Grosso do Sul, Brasil, 22³6’S, 52²0'W). Quatro datações pelo método do ${ }^{14} \mathrm{C}$ obtiveram os seguintes resultados: $11.570 \pm 80$ anos AP (240 cm profundidade), $9.710 \pm$ 80 anos AP (220 cm profundidade), $4.610 \pm 70$ anos AP (130 cm profundidade) e $4.010 \pm 80$ anos AP (29-35 cm profundidade). As espécies de esponjas detectadas foram Heterorotula fistula Volkmer-Ribeiro \& Motta, 1995, Radiospongilla amazonensis Volkmer-Ribeiro \& Maciel, 1983, Corvospongilla seckti Bonetto \& Ezcurra de Drago, 1966 e Trochospongilla repens Hinde, 1888. As duas primeiras espécies são típicas de ambientes lênticos e as duas últimas de ambientes lóticos. As alternâncias desses dois pares de espécies na coluna sedimentar indicam pulsos de inundação na planície do rio Esperança, responsáveis pela acumulação e formação da turfa ao longo das baias marginais desde o início do Holoceno. Também verificou-se a existência de um período mais úmido entre 4.610 and 4.010 anos AP. Os resultados confirmam os estudos palinológicos já produzidos para a região. Esse constitui o primeiro registro fóssil datado para Heterorotula fistula e Trochospongilla repens.

Palavras-chaves: Esponjas de água doce, espículas silicosas, pulsos de inundação, Holoceno, depósitos turfosos.

\section{INTRODUCTION}

An extreme change in the Paraná River hydrology occurred around 8,000 years BP, when, during a wet climatic phase, the increased force of the river cut the channel deeper transforming the former floodplain into a terrace $10 \mathrm{~m}$ above the river bed (Fazenda Boa Vista Terrace) and a new floodplain began to be constructed around 6,000 years BP (Figure 1a) (Stevaux \& Santos, 1998). In the Taquarussu area (Mato Grosso do Sul State), this terrace is in general covered by fluvial lake and eolian sandy deposits with localized peat deposits in the floodplain of the Esperança River, a small drainage that crosses the area (Parolin \& Stevaux, 2001, 2004, in press; Parolin et al., 2006). For the purpose of hydrological 
and paleoenvironmental analysis of the area, three sediment cores were collected across the Esperança river floodplain (Figures $1 \mathrm{~b}$ and 2). In two of those cores freshwater sponge spicules were common.

Continental sponge spicules are useful tools in paleoenvironmental and paleolimnological reconstructions, particularly when considering continental sediments deposited in aquatic environments (Harrison et al., 1979; Hall \& Herrmann, 1980; Harrison, 1988; Sifeddine et al., 1994; Cordeiro et al., 1997; Turcq et al., 1998; Cândido et al., 2000; Gaiser et al., 2004; Volkmer-Ribeiro et al., 2006). Accordingly, the spicules found in the two upper sample cores across Esperança river were used to provide a paleoenvironmental reconstruction of the peaty deposits and make a comparison with a previous hypothesis for the area (Parolin et al., 2006).

\section{STUDY AREA}

The recovered sediments were retrieved from the Fazenda Boa Vista Terrace, in the floodplain of the Esperança River (22 $36^{\prime} 34^{\prime \prime S}$ and $\left.53^{\circ} 11^{\prime} 49^{\prime \prime} \mathrm{W}\right)$, near the right bank of the Upper Paraná River, near the town of Taquarussu (Mato Grosso do Sul State), Southwestern Brazil (Figures 1, 2). The area presents 5 to $10 \mathrm{~m}$ high hills identified by Parolin \& Stevaux $(2001,2004$, in press) as Middle Holocene dunes.
These paleodunes are cut by the Esperança River resulting in a wide swampy floodplain and floodbays with peat deposits (Figure 2). The base of the terrace deposits was dated by Stevaux \& Santos (1998) as 42,500 1,700 years BP. Santos \& Stevaux (2000) suggested that these terrace deposits were formed by gravelly deposits of the Paraná River during a semi-arid period when the river developed a braided pattern with a predominance of flash floods. This system acquired a sandy anastomosed, low energy pattern, at the Pleistocene-Holocene boundary. During the Holocene terrace deposits were re-worked by fluvial and eolian activities. This terrace can be geomorphologically divided into three units (Figure 1A): a) Higher Fazenda Boa Vista Unit - defined by a 200 to $10,000 \mathrm{~m}$ strip within the ancient dune field; b) Lower Fazenda Boa Vista Unit - defined as an incised surface in the former unit with scars and the remains of a sandy drainage network, c) Fazenda Boa Vista Fan Unit - corresponds to the last unit covered by an inactive alluvial fan formed by the Esperança and Baile Rivers.

The regional Late Pleistocene and Holocene climate was defined by (Parolin \& Stevaux, 2001, 2004). Stevaux $(1994,2000)$, who identified four main phases: a) Dry phase at the end of the Pleistocene related to the Last Glacial Maximum; b) Humid phase early to middle Holocene; c) A short dry phase between 3,500 to 1,500 years BP; and d) The present humid phase since 1,500

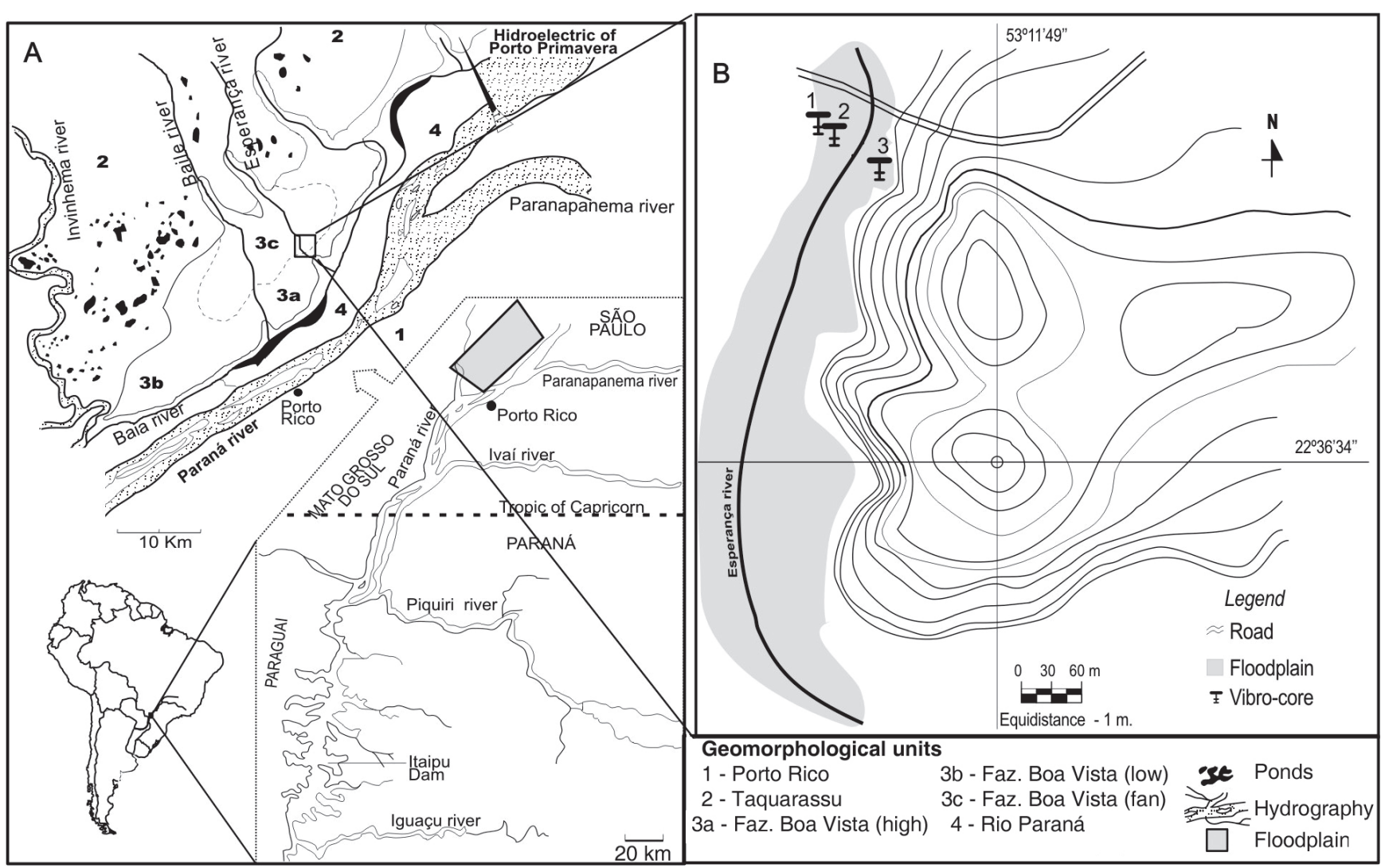

Figure 1. Location map of study with geomorphological units $(A)$ and topographic detail of a paleodune with the location of the cores (B) (modified from Parolin \& Stevaux, 2001; Stevaux, 1993). 


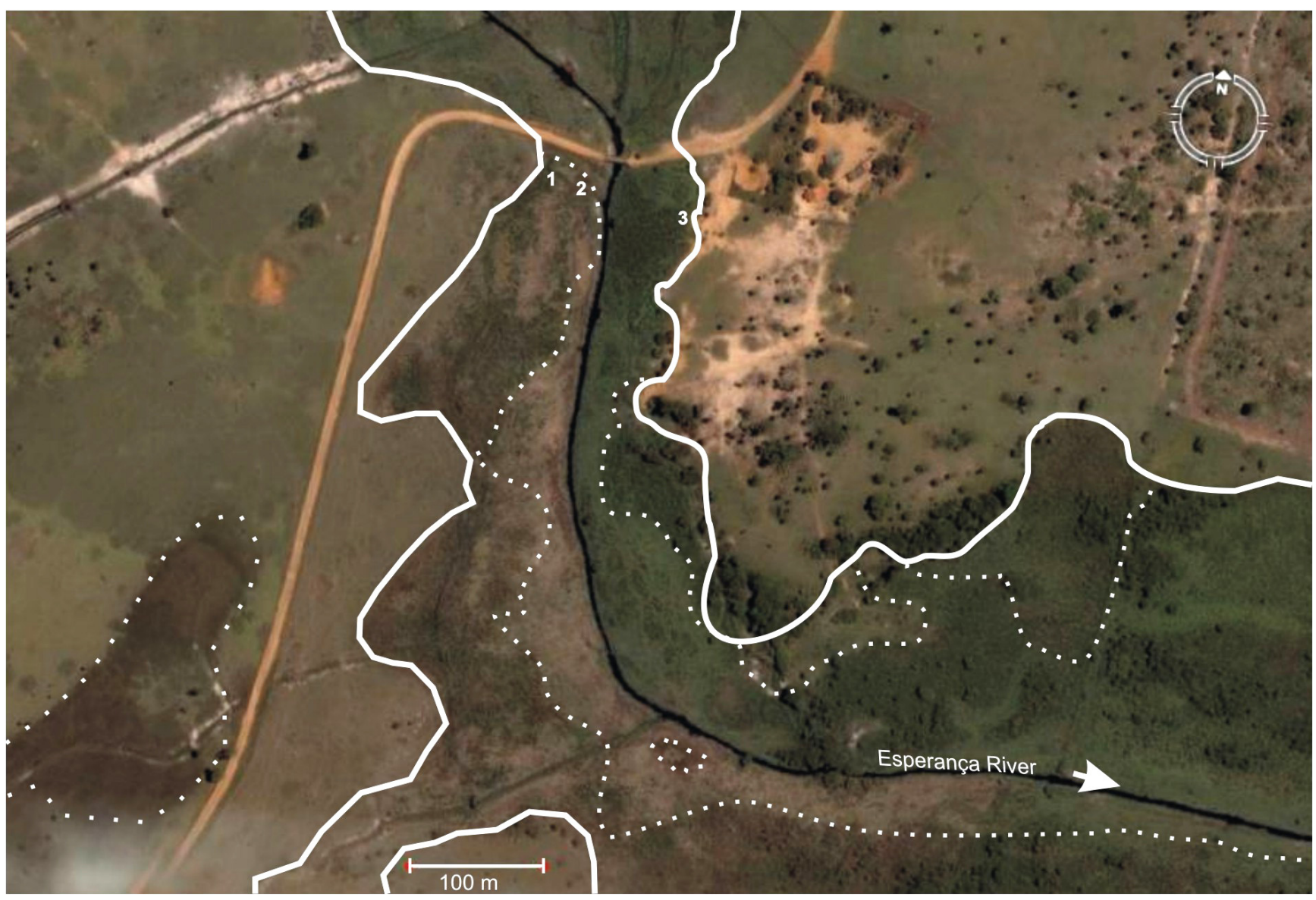

Figure 2. Image of satellite of the studied area with limits (full white line) of the flood plain of Esperança river. The stippled white lines indicate the floodbays with peat deposits (modified from Google Earth $\circledast$ ).

years BP. In a recent paper Parolin et al., (2006) suggest that the short dry phase started around 4,500 years BP, with mobilization of the terrace sand by wind activity and dune formation.

The present climate is humid tropical, with a mean annual temperature of $24^{\circ} \mathrm{C}$ and annual rainfall between 1,250 and 1,500 $\mathrm{mm}$. Precipitation is not well distributed throughout the year and with maximum rainfall in the summer and minimum in the winter(Nimer, 1989).

\section{METHODS}

The work was based on the geomorphological maps of Stevaux (1993) and Parolin \& Stevaux (2001), aerial photographs $(1: 60.000,1966)$, topographic charts of Loanda (SF-22-Y-A-V, 1:100,000 and SF 22-Y-A, 1:250,000), satellite images from Google Earth ${ }^{\circledR}$ software, and topographic field surveys. Three vibro-cores (Martin \& Flexor, 1989) were extracted from the floodplain of the Esperança River (Figures 1, 2, 3). Four samples were dated by ${ }^{14} \mathrm{C}$, (two by BETA ANALYTIC and two by the Center of Nuclear energy in Agriculture/University of São Paulo) and another four samples were dated using thermoluminescence (by the College of Technology of São Paulo FATEC). The longer cores, 2 and 3, were submitted to short spaced sampling for sponge spicules to provide species determination and paleoenvironmental correlation, based on the known habitats of each species (core two at depths of 10,30, 60, 82, 90, 100, 125, 190, 200, $220 \mathrm{~cm}$ and core three at depths of 142,150,180,195 cm). The sediments were processed according to Volkmer-Ribeiro \& Turcq (1996). The resulting siliceous material was suspended in water, placed on microscopic slides, dried, Entellan mounted and permanently sealed with cover slips. Four such slides were prepared from each sediment sample for microscopic examination and photography. The slide collection is deposited at the Laboratory of Paleoenvironment of the Fecilcam (Lepafe) under catalog number LEFAPE 01/2006 and LEFAPE 02/2006 (Figures 4 and 5).

The sponge spicules were identified by the second author based on her considerable experience with South American freshwater sponge taxonomy. The rich slide collection and bibliography available at Museu de Ciências Naturais of Fundação Zoobotânica do Rio Grande do Sul (MCN- FZB) was used in the comparison process. The specific identification keys and spicule nomenclature were provided by Volkmer-Ribeiro \& Pauls (2000) and included: megascleres, spicules that integrate the sponge skeletal network; microscleres, smaller 


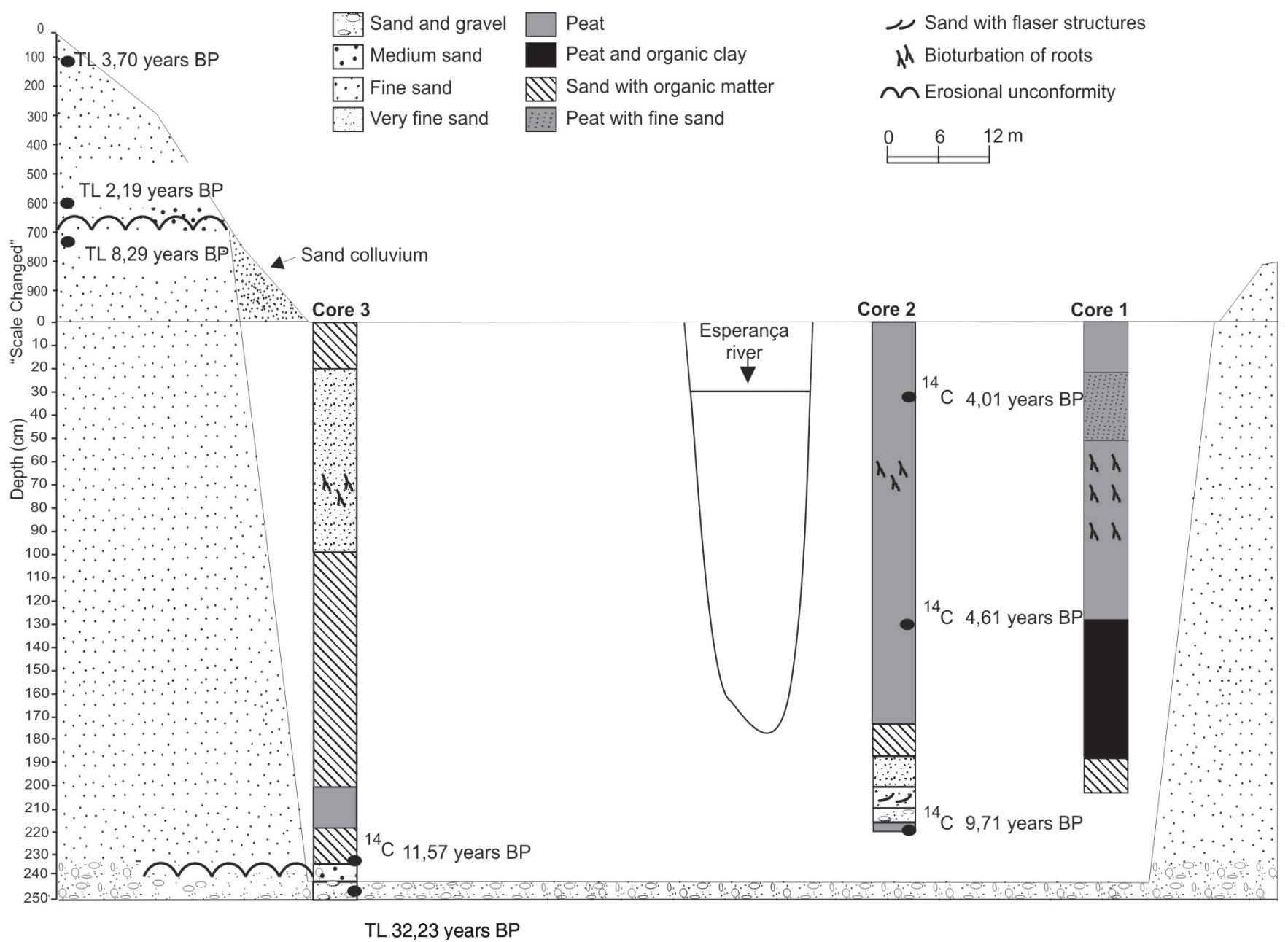

Figure 3. Core profiles with litology, absolute ages and position in relation to the paleodune (adapted from Parolin et al., 2006).

spicules that are mingled in the sponge skeleton and; gemmoscleres, spicules that cover the gemmules and which ultimately define families, genera and species in freshwater sponges.

\section{RESULTS}

\section{Chronology}

The paleodune (Figure 3) was dated at TL 2,100 200

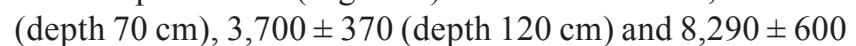
(depth $680 \mathrm{~cm}$ ) years BP (Parolin \& Stevaux, 2001, 2004, in press). The Esperança River floodplain peat deposits obtained with core 3 presented $\left({ }^{14} \mathrm{C}\right)$ ages $11,570 \pm 80$ (depth $240 \mathrm{~cm}$ ), 9,710 \pm 80 (depth $220 \mathrm{~cm}$ ), 4,610 \pm 70 (depth $130 \mathrm{~cm}$ ) and 4,010 $\pm 80($ depth $30 \mathrm{~cm}$ ) years BP. The sandy gravel at the base of core 3 reached (TL) 35,230 \pm 2.200 years BP (Figure 3 ).

\section{Sedimentary sequences}

The sedimentary analysis of core 2 (Figure 4 ) showed 6 depositional sequences: (a) peat (between 220 to 218 $\mathrm{cm}$ and 173 to $0 \mathrm{~cm}$; (b) sand and pebbles between 218 to $210 \mathrm{~cm}$; (c) fine sand with flaser structures between 210 to $211 \mathrm{~cm}$; (d) very fine sand between 211 to $188 \mathrm{~cm}$; (e) sand with organic matter between 188 to $173 \mathrm{~cm}$ and (f) peat between 173 to $0 \mathrm{~cm}$, with bioturbation by roots (110 to $90 \mathrm{~cm}$ and 80 to $60 \mathrm{~cm}$ ). Seven sedimentary sequences were detected in Core 3 from top to bottom (Figure 5): a) sand and pebbles between 240 to $232 \mathrm{~cm}$; b) fine sand between 232 to $228 \mathrm{~cm}$; c) sand with organic matter between 228 to $209 \mathrm{~cm}, 173$ to $96 \mathrm{~cm}$ and 19 to 0 $\mathrm{cm}$; d) peat between 209 to $173 \mathrm{~cm}$ and e) fine sand between 96 to $19 \mathrm{~cm}$, in this sequence there is root bioturbation $(80$ to $60 \mathrm{~cm}$ ).

\section{Spicule analysis}

Large amounts of spicule fragments were seen in core 2 at depths of 60, 90, 140, 190 and $220 \mathrm{~cm}$ (Figure 4 and Table 1). The presence of gemmoscleres and microscleres made it possible to specifically identify the freshwater sponge species present in almost all the sedimentary sequences (at depths $60,82,90,100,140,180,190,220 \mathrm{~cm}$ ). The identified taxa were: Heterorotula fistula Volkmer-Ribeiro \& Motta, 1995 (at depths 60, 90, 100, 140, 190, $220 \mathrm{~cm}$ ); Corvospongilla 


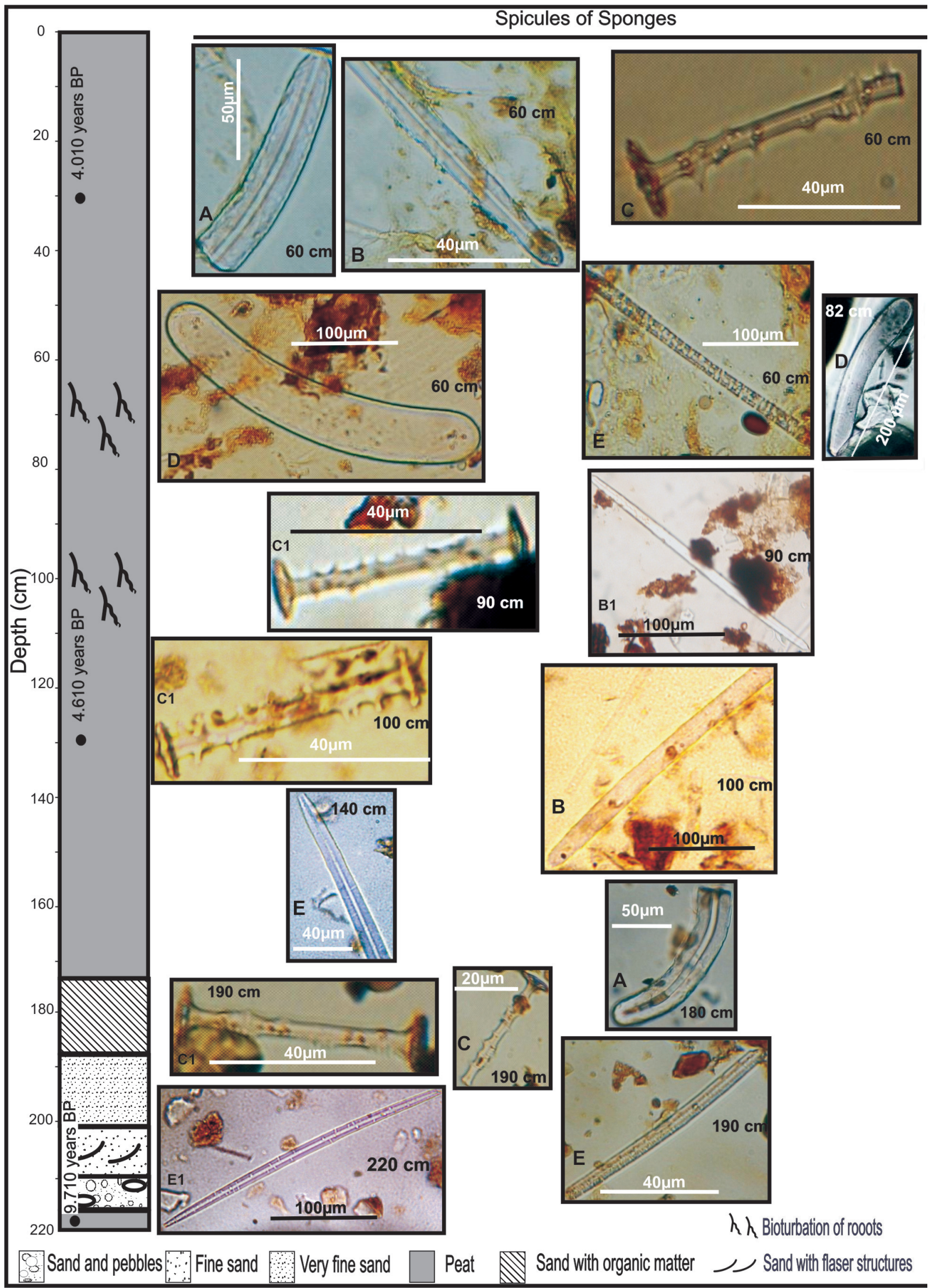

Figure 4. Sedimentary sequences of core 2 with spicule microphotographs: A, megasclere fragment of Corvospongilla seckti; B, fragment of megasclere of Radiospongilla amazonensis; B1, young megasclere of Radiospongilla amazonensis; C, fragment of long gemmosclere of Heterorotula fistula; C1, a long gemmosclere of Heterorotula fistula; D, megascleres of Trochospongilla repens; $\mathbf{E}$, megasclere of Heterorotula fistula; E1, young megasclere of Heterorotula fistula. 


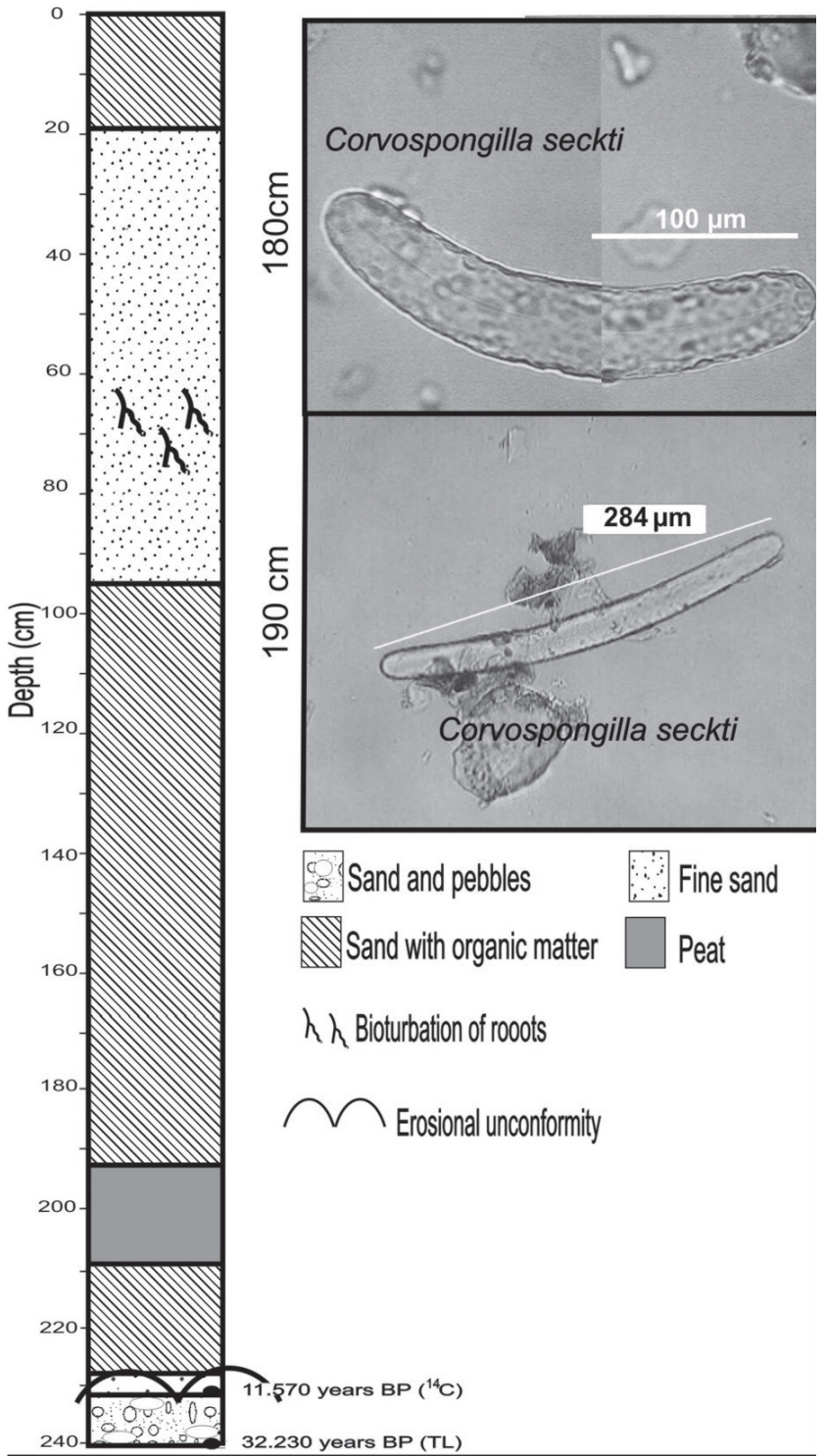

Figure 5. Sedimentary sequences of core 3 and microphotographs of identified of sponge spicules $(190 \mathrm{~cm})$.

seckti Bonetto \& Ezcurra de Drago, 1966 (depths 60, 180 $\mathrm{cm}$ ); Trochospongilla repens Hinde, 1888 (at depths 60, 82 $\mathrm{cm}$ ); gemmosclere and megasclere fragments of Radiospongilla amazonensis Volkmer-Ribeiro \& Maciel, 1983 (at depths 60, 90 and $100 \mathrm{~cm}$ ). At $60 \mathrm{~cm}$ entire megascleres of C. seckti were detected (Figure 4). There were scanty spicule remains in core 3 (Figure 5), however megascleres of $C$. seckti were again detected at 180 and 190 $\mathrm{cm}$. The sediment chronology provides the first dated record of H. fistula $\left({ }^{14} \mathrm{C}\right)$ at 9,710 years BP, and for Trochospongilla repens $\left({ }^{14} \mathrm{C}\right)$ at 4,010 and 4,610 years $\mathrm{BP}$.

\section{DISCUSSION}

The occurrence of a drier climate than the present one during the Holocene has been identified elsewhere in central-southern Brazil by many authors (Barbosa et al.,

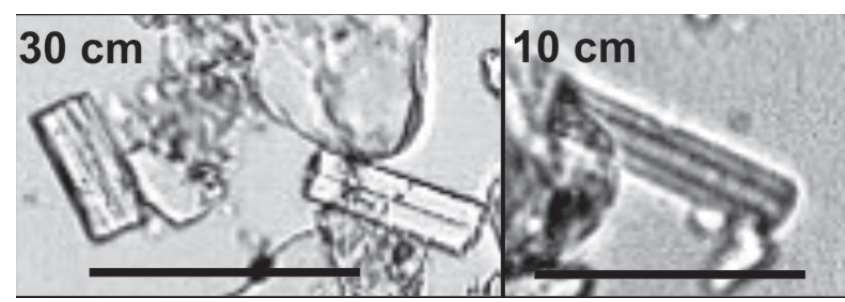

Figure 6. Spicule fragments of sedimentary sequences of core 2, at 30 and $10 \mathrm{~cm}$ depths. Scale bar $=20 \mu \mathrm{m}$.

1990; Van der Hammen, 1991; Thomas \& Thorp, 1995; Ledru, 1993; Ledru et al., 1996; Stevaux, 2000 as example). In the upper catchment region of the Paraná River this dry period was determined by Jabur (1992) and Stevaux (1993, 1994, 2000) at between 3,500 and 1,500 years BP, followed by a humid period from 1,500 years BP. Iriondo \& Kröhling (1995) and Iriondo et al. (1997) suggested that for northeast Argentina this dry period coincided with remobilization of the "loess pampeano", which was deposited during dry periods of the Pleistocene. Stevaux \& Santos (1998) put forth the hypothesis that this same dry event reached the Taquarussu region. Kramer \& Stevaux (1999), Stevaux (2000) and Parolin \& Stevaux (2001, 2004, in press) identified an erosive hiatus of about 9 years BP (between 3,000 to 12,000 years BP) in the depositional sequence of the Taquarussu region and attributed it to intensive eolical activity ca. 3,000 years BP. Paleosols studied by Barczyczyn (2001), Barczyczyn et al. (2001), Medeanic \& Stevaux (2003) and Stevaux et al. (in press) in the same region also present evidence of a drier climate ending around 1,700 years BP.

Parolin et al. (2006) identified a prevalence of herbaceous vegetation (Asteraceae, Ciperaceae and Poaceae) during the Holocene, with the restricted occurrence of arboreal and arbustive vegetation (Fabaceae, Palmaceae and Apocinaceae). These authors believe that the first humid phase, which occurred in the region between 7,500 and 3,500 years BP, was not as intense as elsewhere in central-south Brazil or at least, the short dry period of the Holocene had begun earlier in the study area (around 4,610 years BP). This fact would seem to agree well with the formation of the field dune and eolian activity detected by Parolin \& Stevaux (2001, 2004, in press).

The occurrence of charcoal fragments in core 2, from 230 to $190 \mathrm{~cm}$ depth suggests that the arboreal and arbustive vegetation was concentrated along the water bodies at that time (Parolin et al., 2006). Spicules of the sponge Heterorotula fistula were detected at this same depth. Volkmer-Ribeiro \& Motta (1995) reported the occurrence of $H$. fistula gemmoscleres in the spongillite deposits at the Lagoa dos Datos pond, close to the town of Conceição das Alagoas (Minas Gerais State), southwestern Brazil. These authors suggested that the genus Heterorotula was, at the time, restricted to dry environments in Australia and New Zealand. VolkmerRibeiro et al. (1998) also reported the presence of $H$. 
Table 1. Freshwater sponges spicules identified in core 2. Frequency: absence $=-$, presence $=+$, abundant $=++$.

\begin{tabular}{|c|c|c|c|c|c|}
\hline \multirow{2}{*}{$\begin{array}{l}\text { Depth } \\
\text { (cm) }\end{array}$} & \multicolumn{5}{|c|}{ Sponge espicules } \\
\hline & Fragments & $\begin{array}{l}\text { Heterotula } \\
\text { fistula }\end{array}$ & $\begin{array}{l}\text { Radisopongilla } \\
\text { amazonensis }\end{array}$ & $\begin{array}{c}\text { Trochospongilla } \\
\text { repens }\end{array}$ & $\begin{array}{c}\text { Corvospongilla } \\
\text { seckti }\end{array}$ \\
\hline 10 & + & - & - & - & - \\
\hline 30 & + & - & - & - & - \\
\hline 60 & ++ & $\begin{array}{l}\text { Gemmoscleres } \\
\text { fragments }\end{array}$ & Megascleres & Megascleres & $\begin{array}{l}\text { Megasclere } \\
\text { fragments }\end{array}$ \\
\hline 82 & + & - & - & Megascleres & - \\
\hline 90 & ++ & Gemmoscleres & Megascleres & - & - \\
\hline 100 & + & Gemmoscleres & Megascleres & - & - \\
\hline 125 & + & - & - & - & - \\
\hline 140 & ++ & Megascleres & - & - & - \\
\hline 150 & + & - & - & - & - \\
\hline 165 & - & - & - & - & - \\
\hline 180 & + & - & - & - & $\begin{array}{l}\text { Megasclere } \\
\text { fragments }\end{array}$ \\
\hline 190 & ++ & $\begin{array}{l}\text { Megasclere fragments/ } \\
\text { gemmoscleres }\end{array}$ & - & - & - \\
\hline 200 & + & - & - & - & - \\
\hline 220 & ++ & Megascleres & - & - & - \\
\hline
\end{tabular}

fistula in diatomite deposits at the Lagoa Capão da Horta pond, close to the town of Januário Cicco (Rio Grande do Norte State), northeastern Brazil. Accurate observation of the spicules from core 2 show that the megascleres are incompletely formed (Figure 4). This fact, allied to the presence of gemmoscleres is indicative of the short duration of the water periods in a drier climate. This evidence agrees with the climatological picture for the area proposed by Jabur (1992); Stevaux (1993, 1994, 2000); and Parolin \& Stevaux $(2001,2004)$.

Some authors suggest the existence of a drier phase at the begining of the Holocene in central-southern Brazil (Bombim \& Klant, 1974; Bombim, 1976; Van der Hammen, 1991; Ledru, 1993; Thomas \& Thorp, 1995; Ledru et al., 1996; Behling, 1997). This same climatological phase is proposed for northeastern Argentina $\left(23^{\circ}\right.$ to $\left.30^{\circ} \mathrm{S}\right)$ by Iriondo \& Garcia (1993).

The presence of well preserved megascleres of $C$. seckti in core 3, at depths of 190 and $180 \mathrm{~cm}$ (Figure 3), indicates the existence of a lotic environment at that time. Bonetto \& Ezcurra de Drago $(1970,1966)$ found this species on the rocky bed of the Paraná and Uruguay rivers as well as in their smaller tributaries in northern Argentina. Tavares (1994) and Batista et al. (2003) registered the occurrence of $C$. seckti on blocks, logs and branches in the channel borders or beds of Amazonian rivers. Megascleres of C. seckti are also the predominant spicules in core $2(180 \mathrm{~cm})$. This sediment sequence correlates well with that of core 3 (depth 200 and $210 \mathrm{~cm}$ ) identified as a lotic environment subjected to seasonal short flooding periods (Figure 5).

The small amount of sponge spicules in core 2 at depths 165 and $125 \mathrm{~cm}$, allied to the presence of $H$. fistula megascleres suggests the occurrence of very short water residence, leading to the formation of small isolated water bodies along the floodbays of Esperança River. This evidence corroborates the studies of Parolin \& Stevaux (2001, 2004, in press) and Parolin et al. (2006).

Gemmoscleres of H. fistula and well-formed megascleres of Radiospongilla amazonensis detected in core 2 between 100 and $90 \mathrm{~cm}$ depth (Figure 4), point to an increase in water residence in relation to the previous sequence. Radiospongilla amazonensis is an indicator of the peat layers topping the spongillite deposits in western Minas Gerais State (Volkmer-Ribeiro \& Motta (1995). Cândido et al. (2000) report the occurrence of this species in the early Holocene sandy mud sediments $(9,080$ to 8,860 years BP) at Lake Caracaranã, in Roraima, Brazil.

The well-preserved, robust megascleras of $T$. repens found in core 2 at a depth of $82 \mathrm{~cm}$, aged $\left({ }^{14} \mathrm{C}\right) 4,010$ and 4,610 years BP, indicate a lotic environment. Bonettto \& Ezcurra de Drago (1964) described the occurence of this sponge in the Middle Paraná River (Argentine). De Rosa Barbosa (1984) found it in Ibicuí and Jacuí Rivers in the 
State of Rio Grande do Sul, southern Brazil. Volkmer-Ribeiro \& Hatanaka (1991) registered the species for the River Tocantins, central Brazil and Batista et al. (2003) for the Araguaia River (Tocantins River Basin). All such records support the preference of $T$. repens for rocky substrates at the bottom of turbulent waters.

The sequence where species of sponges characteristic of lentic habitats, such as $R$. amazonensis and $H$. fistula alternate with species of lotic environments (T. repens and $C$. seckti ) point to flooding pulses favoring the residual formation of satellite lentic environments with peat deposits. This situation was identified in core 2, depth $60 \mathrm{~cm}\left({ }^{14} \mathrm{C}\right) 4,010$ and 4,610 years BP and represents a progressive increase in the frequency of flood pulses of the Esperança River (Figure 4) suggesting a probable amelioration of climatological conditions. Parolin et al. (2006) described large amounts of pteridophytic and an extreme reduction in xerophytic pollen during this same interval. This climatic amelioration was correlated to the first humid phase defined by Stevaux (1993, 1994) at the Upper Paraná River catchment area.

The presence of fragments of spicules $(<20 \mu \mathrm{m})$ between depths of 30 and $10 \mathrm{~cm}$ in core 2 (Figures 4 and 6), when compared with other sequences, suggests intense remobilization of channel material by turbulent water flow. This indicates a wetter climate, as proposed in the palynological analysis for this sequence made by Parolin et al. (2006).

\section{CONCLUSIONS}

Based on the occurence of lentic (Heterorotula fistula and Radiospongilla amazonensis) and lotic (C. seckti and T. repens) sponge spicules in sediments recovered at the Esperança River site it is possible to conclude that this river was active during the Holocene with intense periods of flood pulses occurring ca. 4,010 years BP. These flood periods account for the peat formation and the relatively high sedimentary rate of $1.6 \mathrm{~mm} / \mathrm{year}^{-1}$. The first sponge species to appear in and characterize the lentic phase was Heterorotula fistula at the beginning of the Holocene $(9,710$ years BP), followed by Radiospongilla amazonensis during the Middle Holocene (between 4,010 and 4,610 years BP). The periods of more intensive flooding are clearly demarcated at a depth of $180 \mathrm{~cm}$ (cores 3 and 2) firstly by the presence of Corvospongilla seckti and then by Trochospongilla repens megascleres at depths between 82 and $60 \mathrm{~cm}$ (core 2).

\section{ACKNOWLEDGMENTS}

The authors thank to CAPES (MP) and Conselho Nacional de Desenvolovimento Científico e Tecnológico for research fellowship (CVR and JCS); and also to Fundação de Amparo a Pesquisa do Estado de São Paulo for a research grant (JCS). The authors are greatly indebted to Olivo Nonato owner of the Ouro Verde farm, for permission to carry out field work; to Luiz C. R. Pessenda for the ${ }^{14} \mathrm{C}$ datings; to V. Alves, J. Marmontel and José A. da Rocha for assistence with field work; to Maria de Moraes for laboratory analyses and to Severo Lazdan and Eduardo Lazdan for photomicrographs.

\section{REFERENCES}

Barbosa, A.S.; Ribeiro, M.B. \& Shimitz, P.I. 1990. Cultura e ambiente em áreas de cerrado do sudoeste de Goiás. In: M.N. Pinto (ed.) Cerrado - caracterização ocupação e perspectivas. Editora da UNB, p. 67-100.

Batista, T. C. A.; Volkmer-Ribeiro, C.; Darwich, C. \& Alves, L. F. 2003. Freshwater sponges as indicators of floodplain lake environments and of river rocky bottom in Central Amazônia. Amazoniana 18:525-549.

Barczysczyn, O. 2001. Paleossolos na planície de inundação dor rio Paraná: caracterização e interpretação paleoambiental. Programa de Pós-Graduação em Geociências e Meio Ambiente, Universidade Estadual Paulista, Campus Rio Claro, Dissertação de Mestrado, 83 p.

Barczysczyn, O.; Stevaux, J.C.; Medeanic, S. \& Nóbrega, M.T. 2001. Paleossolo da planície de inundação do rio Paraná e suas implicações paleohidrológicas e climáticas. In: CONGRESSO DA ASSOCIAÇÃO BRASILEIRA DE ESTUDOS DO QUATERNÁRIO, 8, 2001. Boletim, Imbé, p. $356-$ 357.

Behling, H. 1997. Late Quaternary vegetation, climate and fire history of the Araucaria forest and campos region from Serra 147 Campos Gerais, Paraná State (South Brazil). Review of Palaeobotany and Palynology, 97:109-121.

Bombim, M. 1976. Modelo paleopedológico evolutivo para o Neoquaternário na região da Campanha Oeste do Rio Grande do Sul. A formação Touro Passo, seu conteúdo fossilífero e pedogênese pós-deposicional. Comunicações do Museu de Ciências da PUCRGS, 15:1-90.

Bombim, M. \& Kant, K. 1974. Evidência paleoclimática em solos do Rio Grande do Sul. In: CONGRESSO BRASILEIRO DE GEOLOGIA, 28, 1974. Anais, Porto Alegre, p. 183194.

Bonetto, A. A. \& Ezcurra De Drago, I. 1970. Esponjas de los afluentes del Alto Parana en la Provincia de Misiones. Acta Zoologica Lilloana, 27:37-58.

Bonetto, A. A. \& Ezcurra de Drago, I. 1966. Nuevas esponjas de água dulce de la Republica Argentina. Physis, 26(71):129140.

Cândido, J. L.; Volkmer-Ribeiro, C.; Filho, F.L.S.; Turcq, B. J.; Desjardins, T. \& Chauvel A. 2000. Microsclere variations of Dosilia pydanieli (Porífera, Spongillidae) in Caracaranã Lake (Roraima - Brazil): Palaeoenvironmental implications. Biociencias, 2:77-92.

Cordeiro, R.C.; Turcq, B.; Suguio, K.; Volkmer-Ribeiro, C.; Silva, A. O.; Sifeddine, A. \& Martin, L. 1997. Holocene environmental changes in Carajás Region (Pará, Brazil) recorded by lacustrine deposits. Verh International Verein Limnology, p.814-817.

Gaiser, E. E.; Brooks, M. J.; Kenney, W. F.; Schelske, C. L. \& Taylor, B. E. 2004. Interpreting the Hydrological history of temporary ponds from chemical and microscopic characterization of siliceous microfossils. Journal of Paleolimnology, 1:63-76.

Iriondo, M.H. \& Kröhling, D.M. 1995. El systema eolico Pampeano. 
Comunicaciones del Museo de Ciencias Naturales Florentino Ameghino, 5(1):1-68.

Iriondo, M. H. \& Garcia, N. O. 1993. Climatic variations in the Argentina plains during the last 18.000 years. Palaeogeography, Palaeoclimatology and Palaeoecology, 101:209-220.

Iriondo, M.H.; Krohling, D.M. \& Orfeo, O. 1997. La Formacion Obera, un Sedimento Eólico Tropical. In: CONGRESSO LATINOAMERICANO DE SEDIMENTOLOGIA, 1, 1997. Memorias, Isla Margarita, Sociedad Venezolana de Geologia, 1:342-348.

Jabur, I.C. 1992. Análise paleoambiental do Quaternário superior na bacia do alto rio Paraná. Programa de Pós-Graduação em Geologia Regional, Universidade Estadual Paulista, Campus Rio Claro, Tese de Doutorado, 184 p.

Hall, K. V. \& Herrmann, S. J. 1980. Paleolimnology of three species of fresh-water sponges (porífera:Spongilidae) from a sediment core of a Colorado semidrainage mountain lake. Trausactions of the American Microscopical Society, 99(1):93-100.

Harrison, F. W. 1988. Utilization of freshwater sponges in paleolimnological studies. Palaeogeography, Palaeoclimatology, Palaeoecology, 62:387-397.

Harrison, F.W.; Gleason, P. J. \& Stone, P. A. 1979. Paleolimnology of lake Okeechobee, Florida: an analysis utilizing spicular components of freshwater sponges (Porifera: Spongillidae). Notulae Naturae 454:1-6.

Kramer, V.M.S. \& Stevaux, J.C. 1999. Thermoluminescence and magnetical susceptibility applied to paleoclimatic reconstruction of the Taquaruçu region (Center-Eastern Brazil), during the Holocene. Boletim Goiano de Geografia (edição especial), 19:3842.

Ledru, M.P. 1993. Late Quaternary evironmental and climatic changes in Central Brazil. Quaternary Research, 39:90-98.

Ledru, M.P.; Braga, P.I.S; Soubiès, F.; Martin, L.; Suguio, K. \& Turcq, B. 1996. The Last 50,000 years in the neotropics (Southern Brazil): evolution of vegetation and climate. Palaeogeography, Palaeoclimatology, Palaeoecology, 123:239-259.

Martin, L. \& Flexor, J.M. 1989. Vibrotestemunhador leve: construção utilização e possibilidades. Associação Brasileira de Estudos do Quaternário, 15 p. (Publicação Especial 1).

Medeanic, S. \& Stevaux, J.C. 2003. Dados palinológicos e partículas de carvão: avaliação de impacto antrópico na região do alto rio Paraná durante o Holoceno In: CONGRESSO DA ASSOCIAÇÃO BRASILEIRA DE ESTUDOS DO QUATERNÁRIO, 9, 2003. Anais de resumos expandidos, Recife, p. 26-29.

Nimer, E. 1989. O Centro-Oeste na organização regional do Brasil. In: IBGE (ed.) Geografia do Brasil, p. 23-34.

Parolin, M. \& Stevaux, J. C. (in press) Dry climate and eolian dune formation in the Middle Holocene in Mato Grosso do Sul State, Center West Brazil. Zeistchrift fur Geomorphologie.

Parolin, M. \& Stevaux, J.C. 2004. Eolian dunes in the Upper Paraná River: Evidence of aridity during the Holocene. In: A. A. Agostinho; L. Rodrigues; L. C. Gomes; S. M. Thomaz; L. E. Miranda (eds.) Stucture and functioning of the Paraná River and its floodplain, Maringá, Editora da Universidade Estadual de Maringá, p. 31-35.

Parolin, M. \& Stevaux, J.C. 2001. Clima seco e formação de dunas eólicas durante o Holoceno Médio em Taquaruçu, Mato Grosso do Sul. Pesquisas em Geociências, 28(2):233-243.

Parolin, M.; Medeanic, S \& Stevaux, J. C. 2006. Registros palinológicos e mudanças ambientais durante o Holoceno de Taquarussu (MS). Revista Brasileira de Paleontologia, 9(1):137-148.

Parolin, M.; Volkmer-Ribeiro, C \& Stevaux, J.C. 2005. Mudanças ambientais durante o Holoceno e final do Pleistoceno indicadas por espongofácies na região de Taquarussu/MS - Brasil. In: CONGRESSO DA ABEQUA, 10, 2005. Boletim de Resumos, Guarapari, 180.

Santos, M. L. \& Stevaux, J. C. 2000. Facies and architectural analysis of chanel macroforms sandy in the upper Paraná river. Quaternary International, 72:87-94.

Sifeddine, A.; Frohlich, F.; Fournier, M.; Martin, L.; Servant, M.; Soubiès, F.; Turcq, B.; Suguio K. \& Volkmer-Ribeiro, C. 1994. La sedimentation lacustre indicateur de changements des paleoenvironments aucours dos 300.000 derniere annees Carajás Amazonie, Brésil. Academie des Sciences, Paris 2 (318):16451652.

Stevaux, J.C. 2000. Climatic events during the Late Pleistocene and Holocene in the Upper Paraná River: Correlation with NE Argentina and South-Central Brazil. Quaternary International, 72:73-85.

Stevaux, J.C. 1994. Upper Paraná River (Brazil) Geomorphology and Paleoclimatology. Quaternary International, 21:143-161.

Stevaux, J.C. 1993. O rio Paraná: Geomorfogênese, sedimentologia e evolução quaternária de seu curso superior. Programa de Pós-Graduação em Geologia Sedimentar, Universidade de São Paulo, Tese de Doutorado, $142 \mathrm{p}$.

Stevaux, J.C.; Barczysczyn, O.; Medeanic, S. \& Nóbrega, M.T. (in press). Paraná River floodplain paleosol: characterization and environmental interpretation. Zeistshrifit für Geomorphologie.

Stevaux, J.C. \& Santos M.L. 1998. Paleohydrological changes in the upper Paraná River (Brazil) during the Late Quaternary: a faciological approach. Paleohydrology and Hydrological Science, 1:273-285.

Tavares, C. M. T. 1994. Comunidades de esponjas de substratos rochosos de rios amazônicos com definição e chave taxonômica para as espécies do gênero Drulia Gray (1867), (PORÍFERA: DEMOSPONGIAE). Programa de Pós-Graduação em Zoologia, Pontifícia Universidade Católica do Rio Grande do Sul, Dissertação de Mestrado, 74 p.

Thomaz, M.F. \& Thorp, M.B. 1995. Geomorphic response to rapid climatic and hydrologic change during the late Pleistocene and early Holocene in the humid and sub-humid tropics. Quaternary Science Review, 14(2):193-207.

Turcq, B.; Sifeddine, A.; Martín, L.; Absy, M.L.; Soubiès. F.; Suguio, K. \& Volkmer-Ribeiro, C. 1998. Amazon forest fires: a lacustrine report 7,000 years. Ambio, 27(2):139-142.

Van der Hammen, T. 1991. Paleoecology of the neotropes: an overview of the state of affairs. In: K. Suguio \& M. Tessler, M. (eds), Proceedings of the Global Changes in South America during the Quaternary, São Paulo. Boletim IG-USP (Publicação Especial), 8:35-55.

Volkmer-Ribeiro C. \& Pauls, S. M. 2000. Esponjas de água dulce (Porifera, Demospongiae) de Venezuela. Acta Biologica Venezuelica, 20(1):1-28.

Volkmer-Ribeiro, C.; Mansur, M. C. D.; Mera, P. A. S. \& Ross, S. M. 1998. Biological Indicators in the Aquatic Habitats of the Ilha de Maracá. In: W. Milliken \& J. Ratter (eds.) Maracá: the biodiversity and environment of an Amazonian rainforest, Jonh Wiley \& Sons Ltd., p. 403-414. 
Volkmer-Ribeiro, C. \& Turcq, B.1996. SEM analysis of siliceous spicules of a freshwater sponge indicate paleoenvironmental changes. Acta Microscópica, 5:186-187.

Volkmer-Ribeiro, C. \& Motta, J. F. M. 1995. Esponjas formadoras de espongilitos em lagoas no triângulo mineiro e adjacências, com indicação de preservação de habitat. Biociências, 2:145169.
Volkmer-Ribeiro, C. \& Hatanaka, T. 1991. Composição e substrato de espongofauna (Porífera) no lago da usina Hidroelétrica de Tucuruí, PA. Iheringia, Ser. Zool., 71:177.

Volkmer-Ribeiro, C.; Marques, D. M.; De Rosa-Barbosa \& R. \& Machado, V. S. 2006. Sponge spicules in sediments indicate evolution of coastal freshwater bodies. Journal of Coastal Research, 39:469-472.

Received in August, 2006; accepted in December, 2006. 